\title{
Effect of Oxygen Concentration on the Growth and Respiratory Efficiency of Acinetobacter calcoaceticus
}

\author{
By GERALDINE A. HARDY† AND EDWIN A. DAWES* \\ Department of Biochemistry, University of Hull, Hull HU6 $7 R X, U K$
}

(Received 7 September 1984)

\begin{abstract}
Maximum molar growth yields on oxygen $\left(Y_{\mathrm{O}_{2}}^{\max }\right)$ and succinate $\left(Y_{\text {succinate }}^{\max }\right)$ were not affected when carbon-limited Acinetobacter calcoaceticus NCIB 8250 was changed to oxygen limitation. $\rightarrow \mathrm{H}^{+} / \mathrm{O}$ quotients for cells grown with succinate- or ammonium-limitation did not differ significantly from those obtained with oxygen-limited cells. The levels of cytochromes $b$ and $o$ remained constant at 0.13 and $0.05 \mathrm{nmol}(\mathrm{mg} \text { protein })^{-1}$ respectively in crude cell-free extracts of succinate-limited organisms grown at high $(80 \mathrm{mmHg})$ or low $(5-10 \mathrm{mmHg})$ dissolved oxygen tension respectively. Their levels increased in oxygen-limited conditions, when cytochrome $a_{2}$ (d) was additionally synthesized and organisms exhibited increased resistance to cyanide inhibition of respiration. It is concluded that the respiratory efficiency of $\boldsymbol{A}$. calcoaceticus NCIB 8250 is unaffected by oxygen concentration under the conditions studied. Theoretical calculations are presented for maximum molar growth yields on succinate and oxygen and these are compared with experimental values. Although the effective $\mathrm{P} / \mathrm{O}$ ratio is only about unity, energy is probably conserved at two sites of oxidative phosphorylation and this is independent of the de novo synthesis of cytochrome $a_{2}(d)$ under conditions of oxygen limitation. Possible reasons for the observed low molar growth yields are discussed.
\end{abstract}

\section{INTRODUCTION}

There are many reports in the literature about the effects of oxygen on the growth and physiology of facultative anaerobes (Wimpenny, 1969; Harrison, 1973, 1976; Keevil et al., 1977, 1979; Wales \& Cartledge, 1980). Similar studies with obligate aerobes, however, are sparse, and much of the published work has centred on the nitrogen-fixing genus Azotobacter (Dalton \& Postgate, 1969; Nagai et al., 1969; Drozd \& Postgate, 1970; Nishizawa et al., 1971). Excess aeration causes a deletion of sites I and II of oxidative phosphorylation, and thereby a decrease in respiratory efficiency in Azotobacter vinelandii (Ackrell \& Jones, $1971 a, b$ ). This phenomenon is manifested by very high respiratory rates when growing cells are exposed to high oxygen tensions, and is thought to be a mechanism to protect their oxygen-sensitive nitrogenase.

The possibility exists that non-nitrogen-fixing aerobes do not respire at greater rates, and therefore less efficiently, in highly aerated conditions, as they have no need to protect a nitrogenase enzyme. This study was designed to investigate the effect of varying oxygen tensions on the growth and respiration of the aerobe Acinetobacter calcoaceticus NCIB 8250. It was undertaken as part of a survey of the response to oxygen concentration of non-nitrogen-fixing aerobes which display different patterns of carbohydrate metabolism, e.g. Pseudomonas aeruginosa (Mitchell \& Dawes, 1982), with intracellular and extracellular (periplasmic) pathways of glucose metabolism (Midgley \& Dawes, 1973; Whiting et al., 1976a, b), as compared with $A$. calcoaceticus, which does not significantly utilize glucose as a carbon source,

† Present address: Microbial Resources Ltd, 10-12 Deacon Way, Scours Lane, Reading RG3 6AZ, UK.

Abbreviation: d.o.t., dissolved oxygen tension. 
to complement our previous work with Azotobacter beijerinckii (Senior et al., 1972; Jackson \& Dawes, 1976; Ward et al., 1977; Carter \& Dawes, 1979).

Ensley et al. (1981) reported that the respiratory efficiency of $A$. calcoaceticus HOl-N is independent of oxygen concentration and that the redox chain is divided into two equivalent sites of energy conservation. Our results support the conclusion that there are two sites of oxidative phosphorylation and that they are independent of the aeration conditions employed.

\section{METHODS}

Organism. Acinetobacter calcoaceticus NCIB 8250 was supplied by Professor C. A. Fewson (Department of Biochemistry, Glasgow University, UK). Stock cultures were maintained at $4^{\circ} \mathrm{C}$ in Oxoid cooked meat medium and sub-cultured at six-monthly intervals.

Growth in the chemostat. The organism was grown at $30^{\circ} \mathrm{C}$ in a Porton-type chemostat (Herbert et al., 1965) with a 2.15 litre working volume. The growth medium consisted of $\left(\mathrm{g} \mathrm{l}^{-1}\right): \mathrm{KH}_{2} \mathrm{PO}_{4}, 4.0 ;\left(\mathrm{NH}_{4}\right)_{2} \mathrm{SO}_{4}, 2.0$; $\mathrm{MgSO}_{4} .7 \mathrm{H}_{2} \mathrm{O}, 0.4$; sodium succinate. $6 \mathrm{H}_{2} \mathrm{O}$ as carbon source, 13.5 ; trace metals solution (Beggs \& Fewson, 1977), $2 \mathrm{ml}$. In conditions of adequate aeration this medium was carbon-limiting and yielded $1.8 \mathrm{mg}$ organism dry wt $\mathrm{ml}^{-1}$. The complete medium was prepared and sterilized by passage through a Sartorius membrane filter $(142 \mathrm{~mm})$ with a pore size of $0.2 \mu \mathrm{m}$. A Sartorius pad pre-filter was also used $(127 \mathrm{~mm})$. Media for the growth of chemostat inocula were sterilized at $105 \mathrm{kPa}$ and $121^{\circ} \mathrm{C}$ for $15 \mathrm{~min}$. $\mathrm{MgSO}_{4}$ solutions were sterilized separately and appropriate amounts added aseptically; trace metals were not included for inoculum production.

Measurement of cell density and growth rates. Growth rates were calculated from semilogarithmic plots of $\mathrm{OD}_{500}$ (measured in a Pye-Unicam SP600 spectrophotometer) versus time, determined during the period of batch growth following inoculation of the chemostat. Dry weights of cells were determined directly by centrifuging a known volume of culture at $16000 \mathrm{~g}$ for $10 \mathrm{~min}$ on a Sorvall RC2B centrifuge. The pellet was washed once in distilled water, then resuspended in a small volume of distilled water and dried at $80^{\circ} \mathrm{C}$, in a pre-weighed, dry glass vial, to constant weight.

Measurement and control of dissolved oxygen tension (d.o.t.). A galvanic probe was used for d.o.t. measurements. The probe was calibrated before each experiment by equilibrating sterile medium, at $30^{\circ} \mathrm{C}$, with known mixtures of oxygen and oxygen-free nitrogen. The partial pressure of oxygen in the liquid phase $\left(T_{\mathrm{L}}\right)$ was taken to be in equilibrium with that in the gas phase $\left(T_{g}\right)$ and was calculated as follows:

$$
T_{\mathrm{L}}=\left(P+P_{\mathrm{b}}-\mathrm{SVP}\right)(C / 100)
$$

where $P=$ atmospheric pressure $(\mathrm{mmHg}), P_{\mathrm{b}}=$ back pressure in the culture vessel $(\mathrm{mmHg}), C=$ percentage of $\mathrm{O}_{2}$ in the gas phase, and SVP = saturated vapour pressure of water at calibration temperature.

Where control of d.o.t. was required this was effected by means of a Leeds and Northrup series 60 controller using a three-action CAT control unit. An electro-pneumatic transducer was operated by compressed air at $70 \mathrm{kPa}$, and fed its output signal to a control valve through which pure oxygen was passed.

Measurement of gases. The oxygen and carbon dioxide content of gases flowing into and out of the chemostat, and the gas flow rates, were measured as described by Senior et al. (1972).

Analysis for residual nutrients. The concentration of succinate in sterile media and culture supernatants was measured by an adaptation of the method of Holdeman et al. (1977). Methyl malonic acid was included as an internal standard. Methyl esters were detected with the flame ionization detector of a Pye Unicam series 104 gasliquid chromatograph. The methyl esters of succinate and methyl malonic acid were separated in a $1.9 \mathrm{~m}$ glass column, packed with $10 \%$ diethylene glycol succinate on $80 / 100$ Supelcoport. Oxygen-free nitrogen was used as the carrier gas at a flow-rate of $20 \mathrm{ml} \mathrm{min} \mathrm{m}^{-1}$.

The concentration of ammonium ions in sterile media and culture supernatants was measured using the method of Chaney \& Marbach (1962).

Acetate present in culture supernatants was detected qualitatively by gas-liquid chromatography with a Pye Unicam series 104 chromatograph fitted with a flame ionization detector system. Samples $(0.5$ to $5 \mu)$ of clarified, acidified supernatants were injected into a $1.9 \mathrm{~m}$ glass column packed with Porapak QS. The carrier gas was oxygen-free nitrogen flowing at a rate of $50 \mathrm{ml} \mathrm{min}^{-1}$. The operational temperature was $210^{\circ} \mathrm{C}$. Quantitative measurements of acetate were obtained using the acetate kinase assay of Holz \& Bergmeyer (1978).

Determination of in situ metabolic quotients and molar growth yields. The in situ specific oxygen uptake rate, $q_{\mathrm{O}_{2}}$, was measured using an adaptation of the method of Harrison \& Loveless (1971). The following equation was used:

$$
9 \mathrm{O}_{2}=\left(\mathrm{C}_{1} \mathrm{~F}_{1} / 100-\mathrm{C}_{2} \mathrm{~F}_{2} / 100\right)(60 / x v)(P / 760)(273 / T+273)(1 / 22 \cdot 4)
$$

where $C_{1}=$ percentage of $\mathrm{O}_{2}$ in the gas supply, $C_{2}=$ percentage of $\mathrm{O}_{2}$ in the effluent gas, $\mathrm{F}_{1}=$ gas supply flowrate $\left(\mathrm{ml} \mathrm{min}^{-1}\right), \mathrm{F}_{2}=$ effluent gas flow-rate $\left(\mathrm{ml} \mathrm{min}^{-1}\right), x=$ culture dry wt $\left(\mathrm{g}^{-1}\right)$, and $v=$ culture volume (l).

The specific rate of $\mathrm{CO}_{2}$ evolution, $q_{\mathrm{CO}_{2}}$, was measured in the same way, but with the omission from the equation of terms relating to the gas supply. Molar growth yields on oxygen and carbon dioxide, $Y_{\mathrm{O}_{2}}$ and $\mathrm{Y}_{\mathrm{CO}_{2}}$ 
respectively, were calculated from the general equation $Y=D / q$, where $D=\operatorname{dilution}$ rate $\left(\mathrm{h}^{-1}\right)$ and $q=$ specific utilization/evolution rate $\left(\mathrm{mol} \mathbf{g}^{-1} \mathbf{h}^{-1}\right)$.

The molar growth yield on succinate, $Y_{\text {succinate }}$, was calculated as $Y_{\text {succinate }}=x /\left(s_{\mathrm{r}}-s\right)$, where $x$ is given, $s_{\mathrm{r}}=$ inflowing succinate concentration $(\mathrm{M})$ and $s=$ outflowing succinate concentration $(\mathrm{M})$. The specific succinate utilization rate, $q_{\text {succinate }}\left(\mathrm{mmol} \mathrm{g}^{-1} \mathrm{~h}^{-1}\right)$, was calculated from $q_{\text {succinate }}=D / Y_{\text {succinate }} \times 10^{3}$.

Maximum molar growth yields on oxygen, carbon dioxide and succinate were determined by plotting metabolic quotients, $q$, measured at different growth rates, $\mu$, against $\mu$. Linear plots were obtained which obeyed the general equation $q=\mu / Y^{\max }+m$. Slopes and intercepts, determined by linear regression analysis, of these plots gave reciprocal maximum molar growth yields $\left(1 / Y^{\max }\right)$, and maintenance coefficients $(m)$ respectively.

$\rightarrow H^{+} / O$ quotients. Respiration-driven proton translocation was measured essentially as described by Mitchell \& Moyle (1967). Suspensions of whole cells were prepared from either carbon (succinate)-limited, ammoniumlimited or oxygen-limited cultures by washing them twice in $150 \mathrm{mM}-\mathrm{KCl} / 3 \mathrm{mM}-\mathrm{glycylglycine} \mathrm{buffer} \mathrm{(pH} \mathrm{7 \cdot 0).} \mathrm{Cell}$ suspensions were added to a lightly buffered anaerobic $\mathrm{KCl} / \mathrm{KSCN}$ solution in the reaction chamber, to a final concentration of 1 to $4 \mathrm{mg}$ dry wt $\mathrm{ml}^{-1}$. Volumes $(30-100 \mu \mathrm{l})$ of air-saturated $150 \mathrm{mM}-\mathrm{KCl}$ were added to the cell suspension and acidification of the external medium due to respiration-driven proton extrusion was quantified by reference to known concentrations of $5 \mathrm{mM}-\mathrm{HCl}$ in $150 \mathrm{mM}-\mathrm{KCl} . \rightarrow \mathrm{H}^{+} / \mathrm{O}$ quotients, which were measured in the presence of 50 to $170 \mathrm{mM}-\mathrm{KSCN}$, were calculated from decay curves which were extrapolated to zero time.

Cytochrome spectra. Crude cell-free extracts were prepared for cytochrome determinations by sedimenting steady-state cells at $4^{\circ} \mathrm{C}$ and $16000 \mathrm{~g}$ for $10 \mathrm{~min}$ on a Sorvall RC2B centrifuge. The cells were washed twice in

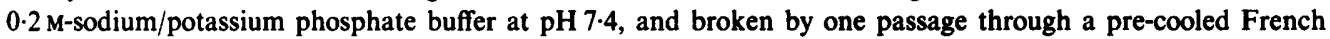
pressure cell (Milner et al., 1950). Cell debris and unbroken cells were removed by centrifuging at $27000 \mathrm{~g}$ for $20 \mathrm{~min}$; extracts were held on ice stored at $4{ }^{\circ} \mathrm{C}$ for not more than $24 \mathrm{~h}$.

Difference spectra of reduced minus oxidized, and reduced-plus-carbon monoxide minus reduced cytochromes were recorded by scanning appropriately treated samples between 390 and $700 \mathrm{~nm}$ in the turbid sample position of a Pye Unicam SP1800 recording spectrophotometer. Cytochromes were oxidized either with air or by the addition of solid potassium ferricyanide. Reduction of cytochromes was effected either by the addition of solid sodium dithionite or by the addition of $100 \mu 110 \mathrm{~mm}$-NADH. Cytochrome levels were quantified using the wavelength pairs and absorption coefficients reported by Asperger et al. (1978).

Determination of cyanide inhibition of respiration. Oxygen uptake was determined on washed cells suspended to a concentration of 15 to $20 \mathrm{mg} \mathrm{ml}^{-1}$ in ice-cold growth medium minus succinate, trace metals and magnesium sulphate and adjusted to $\mathrm{pH} 7.2$ with $5 \mathrm{M}-\mathrm{NaOH}$ (minimal medium buffer). A Clark-type electrode mounted into the base of a jacketed polycarbonate reaction vessel (Rank Ltd) was used to measure respiratory rates and this was calibrated by the method of Robinson \& Cooper (1970). Respiratory rates in the presence of 5 to $700 \mu \mathrm{M}-\mathrm{KCN}$ were determined by adding the required volume of $34 \mathrm{mM}-\mathrm{KCN}$ (prepared daily in minimal medium buffer, and held on ice) to buffer in the reaction vessel (volume $3.4 \mathrm{ml}$ ). Endogenous respiratory rates were followed for $4 \mathrm{~min}$ after adding cells to give a bacterial concentration of 0.3 to $0.4 \mathrm{mg} \mathrm{m}^{-1}$ in the vessel. Respiration was then stimulated by the addition of succinate to a concentration of $29.4 \mathrm{mM}$. Oxygen-uptake rates were calculated from the initial linear portion of a trace recorded on a linear flat-bed recorder (Servoscribe). Uninhibited succinatestimulated respiratory rates were taken as the $100 \%$ level and these were determined periodically throughout each experiment, to detect any cell instability and to assess the effects of exposure to cyanide on the electrode performance. Total oxygen uptake rates stimulated by succinate were calculated without correction for endogenous respiratory activity.

Theoretical calculations of maximum molar growth yields. Theoretical values of $Y_{\text {succinate }}^{\max }$ and $Y_{\mathrm{O}_{2}}^{\max }$ were calculated (Table 2) by the method of Stouthamer (1979). The empirical formula for a mole of $A$. calcoaceticus NCIB 8250 was derived from elemental analyses on succinate-limited cells (Fewson, 1985).

\section{RESULTS}

\section{Experimental molar growth yields and maintenance coefficients}

Maximum molar growth yields on oxygen $\left(Y_{\mathrm{O}_{2}}^{\max }\right)$ and succinate $\left(Y_{\text {succinate }}^{\max }\right)$ were determined on continuously cultured organisms with succinate as carbon source. Specific utilization rates of the two substrates, $q_{\mathrm{O}_{2}}$ and $q_{\text {succinate }}$ respectively, were determined at different growth rates, and linear plots of $q$ versus $\mu$ obtained (Figs 1 and 2) such that the reciprocal of the slope gave $Y^{\max }$ and the intercept provided $m$, the maintenance coefficient (Pirt, 1975). The values of $Y_{\mathrm{O}_{2}}^{\max }$ determined under conditions of carbon limitation at $5-10 \mathrm{mmHg}$ and $80 \mathrm{mmHg}$ d.o.t. were 25.75 and $23.15 \mathrm{~g} \mathrm{~mol}^{-1}$ respectively. These values did not vary significantly from the figure of $22.57 \mathrm{~g} \mathrm{~mol}^{-1}$ obtained with oxygen-limited cells $\left(0 \mathrm{mmHg}\right.$ d.o.t.). $Y_{\text {succinate }}^{\max }$ was also independent of the nutrient limitation and had a value of $42.52 \mathrm{~g} \mathrm{~mol}^{-1}$ for carbon-limited cells growing at 

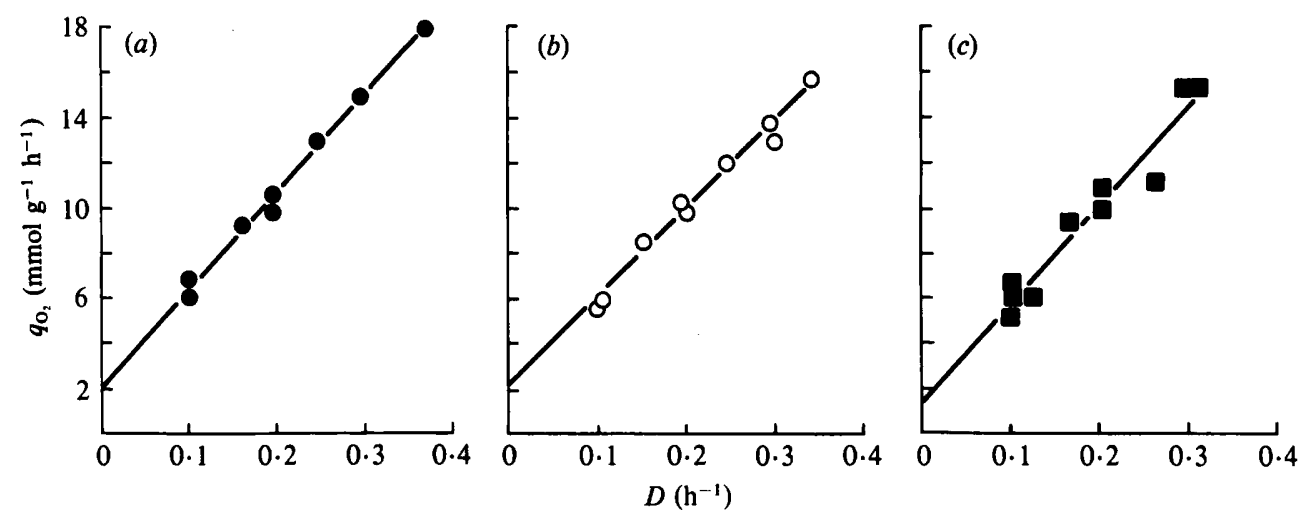

Fig. 1. Determination of $Y_{\mathrm{O}_{2}}^{\max }$ and $m_{\mathrm{O}}$ for A. calcoaceticus NCIB 8250 growing in minimal salts medium with succinate. Aeration conditions in the chemostat were $(a) 80 \mathrm{mmHg}\left(\Theta_{)}\right),(b) 5-10 \mathrm{mmHg}$ $(O)$, and $(c) 0 \mathrm{mmHg}(\mathbb{\square})$ d.o.t. The plots for each aeration regime were obtained from the pooled results of two chemostat runs.

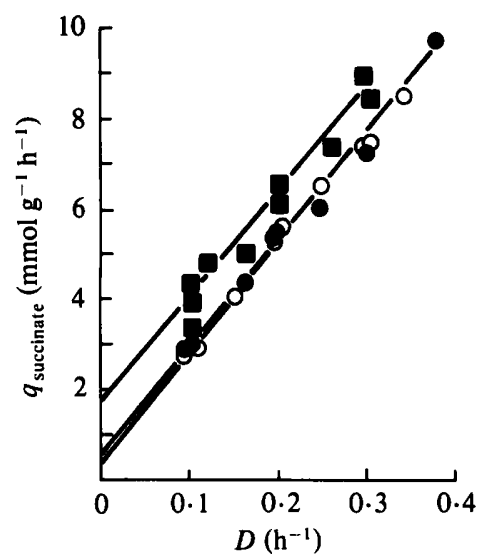

Fig. 2. Determination of $Y_{\text {succinate }}^{\max }$ and $\boldsymbol{m}_{\text {succinate }}$ for $A$. calcoaceticus NCIB 8250 growing in minimal salts medium with succinate. Aeration conditions in the chemostat were $80 \mathrm{mmHg}(\mathrm{O}), 5-10 \mathrm{mmHg}(\mathrm{O})$ and $0 \mathrm{mmHg}(\square)$ d.o.t. The plots for each aeration regime were obtained from the pooled results of two chemostat runs.

Table 1. Maximum molar growth yields and maintenance coefficients on succinate and oxygen

Maximum molar growth yields were calculated from the reciprocal of the slopes of the plots shown in Figs 1 and 2. Each slope was determined by linear regression analysis. The intercepts of the lines gave the maintenance coefficients of the respective nutrients.

$\begin{array}{rlccc}\text { Limiting nutrient } & \ldots & \text { Carbon } & \text { Carbon } & \text { Oxygen } \\ \text { Steady-state d.o.t. }(\mathrm{mmHg}) & \ldots & 80 & 5-10 & 0 \\ Y_{\mathrm{O}_{2}}^{\max }\left(\mathrm{g} \mathrm{mol}^{-1}\right) & & 23.15 & 25.75 & 22.57 \\ m_{\mathrm{O}}\left(\mathrm{mmol} \mathrm{g}^{-1} \mathrm{~h}^{-1}\right) & & 1.99 & 2.13 & 1.49 \\ Y_{\text {succinate }}^{\max }\left(\mathrm{g} \mathrm{mol}^{-1}\right) & 42.09 & 42.52 & 42.66 \\ m_{\text {succinate }}\left(\mathrm{mmol} \mathrm{g}^{-1} \mathrm{~h}^{-1}\right) & 0.53 & 0.56 & 1.50\end{array}$

5-10 $\mathrm{mmHg}$ d.o.t. (Table 1). In contrast, $m_{\text {succinate }}$ increased about threefold to $1.5 \mathrm{mmol} \mathrm{g}^{-1} \mathrm{~h}^{-1}$ when cells were oxygen limited (Table 1), but there was no corresponding increase in $m_{\mathrm{O}_{2}}$. Carbon dioxide evolution for maintenance purposes increased about twofold to $4.04 \mathrm{mmol} \mathrm{g}^{-1} \mathrm{~h}^{-1}$ in oxygen-limited cultures. 
Table 2. Theoretical calculations of maximum molar growth yields on succinate and oxygen

The theoretical value for $Y_{\text {succinate }}^{\max }$ is calculated using the method of Stouthamer (1979). The elementary formula for $A$. calcoaceticus (corresponding to a molecular weight of 100 ) is derived from that of Fewson (1985) and used to construct an equation for assimilation from succinate:

$$
\mathrm{C}_{4} \mathrm{H}_{6} \mathrm{O}_{4}+0.88 \mathrm{NH}_{3}+1.18 \mathrm{H}_{2}\left(\text { as } \mathrm{NADH}_{2}\right) \rightarrow \mathrm{C}_{4} \mathrm{H}_{6.64} \mathrm{O}_{1.82} \mathrm{~N}_{0.88}+2.18 \mathrm{H}_{2} \mathrm{O}
$$

The consumption of $1.18 \mathrm{H}_{2}$ is included in the equation where ' $\mathrm{H}_{2}$ ' indicates the requirement for reducing equivalents in the formation of biomass. By putting $Y_{\text {succinate }}^{\max }$ equal to $x$, and on the assumption that the complete dissimilation of 1 mol succinate yields $5 \mathrm{~mol} \mathrm{NADH}_{2}, 2 \mathrm{~mol} \mathrm{FADH}_{2}$ and 1 mol ATP, equations for the amount of succinate assimilated and dissimilated, and the reducing power available for oxidation, are derived: succinate assimilated $=x / 100$, succinate dissimilated $=$ $1-(x / 100) ; \mathrm{NADH}_{2}$ required for assimilation $=1 \cdot 18 x / 100$; reducing equivalents available for oxidation $=5-(5 x / 100)-(1 \cdot 18 x / 100)=(5-6 \cdot 18 x / 100) \mathrm{NADH}_{2}$, and $2-(2 x / 100) \mathrm{FADH}_{2}$. Total ATP gain from the utilization of $1 \mathrm{~mol}$ succinate is described by equations derived on the basis of one, two or three phosphorylation sites. Since $x=Y_{\text {succinate }}^{\max }=\left(Y_{A T P}^{\max }\right)$.(total ATP per mol succinate), each equation is solved for $x$ by substituting a theoretical value for $Y_{\mathrm{ATP}}^{\max }$; in this case $15.4 \mathrm{~g} \mathrm{~mol}^{-1}$ is used, which is the theoretical value for growth on malate (Stouthamer, 1979). The calculated value for $Y_{\text {succinate }}^{\max }$ is then divided by the total oxygen uptake to give the theoretical value for $Y \delta_{2}^{\text {ax }}$.

$$
\text { No. of phosphorylation sites ... } 1
$$

2 3

Source of ATP:

\begin{tabular}{lccc}
$\mathrm{NADH}_{2}$ & $5-(6 \cdot 18 x / 100)$ & $10-(12 \cdot 36 x / 100)$ & $15-(18 \cdot 54 x / 100)$ \\
FADH & & $2-(2 x / 100)$ & $4-(4 x / 100)$ \\
Substrate-level phosphorylation & $1-(x / 100)$ & $1-(x / 100)$ & $1-(x / 100)$ \\
\hline Total ATP & $6-(7 \cdot 18 x / 100)$ & $13-(15 \cdot 36 x / 100)$ & $20-(23 \cdot 54 x / 100)$ \\
Thus $Y_{\text {suxcinate }}^{\max }$ & 43.88 & 59.49 & 66.59 \\
and $Y_{\mathrm{O}_{2}}^{\max }$ & $25 \cdot 81$ & $56 \cdot 12$ & $85 \cdot 37$
\end{tabular}

\section{Theoretical molar growth yields}

An empirical formula of $\mathrm{C}_{4} \mathrm{H}_{6.64} \mathrm{~N}_{0.88} \mathrm{O}_{1.82} \mathrm{P}_{0.07} \mathrm{~S}_{0.05}$ derived from analyses of succinatelimited $A$. calcoaceticus NCIB 8250 (Fewson, 1985) was used to construct the following assimilation equation for growth with succinate and ammonia:

$$
\mathrm{C}_{4} \mathrm{H}_{6} \mathrm{O}_{4}+0.88 \mathrm{NH}_{3}+1 \cdot 18 \mathrm{H}_{2} \rightarrow \mathrm{C}_{4} \mathrm{H}_{6.64} \mathrm{~N}_{0.88} \mathrm{O}_{1.82}+2 \cdot 18 \mathrm{H}_{2} \mathrm{O}
$$

Using this equation, $Y_{\text {succinate }}^{\max }$ and $Y_{\mathrm{O}_{2}}^{\max }$ values of 43.9 and $25.8 \mathrm{~g} \mathrm{~mol}^{-1}$ respectively were calculated (Table 2) on the assumption that there was only one site of oxidative phosphorylation. These values are very close to those derived experimentally. If it is assumed that there are two phosphorylation sites then the theoretical values of $Y_{\text {succinate }}^{\max }$ and $Y_{\mathrm{O}_{2}}^{\max }$ increase to 59.5 and $56 \cdot 1 \mathrm{~g} \mathrm{~mol}^{-1}$, and for three sites they become 66.6 and $85.4 \mathrm{~g} \mathrm{~mol}^{-1}$ respectively (Table 2).

\section{Cytochrome composition}

Reduced minus oxidized difference spectra determined on crude cell-free extracts had absorption maxima at 560 and 530-532 nm, consistent with the $\alpha$ and $\beta$ peaks of cytochrome $b$, under all the conditions studied (Fig. 3). Also present in all extracts was cytochrome $o$, characterized by a peak in the Soret region at $417-420 \mathrm{~nm}$ of reduced-plus-carbon monoxide minus reduced difference spectra (Fig. 3). In extracts prepared from oxygen-limited cells an absorption maximum at $630 \mathrm{~nm}$ of reduced minus oxidized spectra was also present (Fig. 4), and this is consistent with the presence of cytochrome $a_{2}(d)$. The function of this last cytochrome as a terminal oxidase is indicated by the shift in absorption to $640 \mathrm{~nm}$ after treatment with carbon monoxide (Fig. 3). This pattern of cytochrome synthesis is consistent with results published by Ensley \& Finnerty (1980) for Acinetobacter sp. HOl-N. Further evidence for the synthesis of cytochrome $a_{2}$ under oxygen-limited conditions $(0 \mathrm{mmHg}$ d.o.t. $)$ is provided by the resistance of cells from this steady state to respiratory inhibition by cyanide $(170 \mu \mathrm{M}$-cyanide caused $50 \%$ inhibition) compared with that of carbon-limited $(80 \mathrm{mmHg}$ d.o.t.) cells $(45 \mu \mathrm{M}$-cyanide caused $50 \%$ inhibition). This pattern of cyanide inhibition was also noted by Ensley \& Finnerty (1980). 


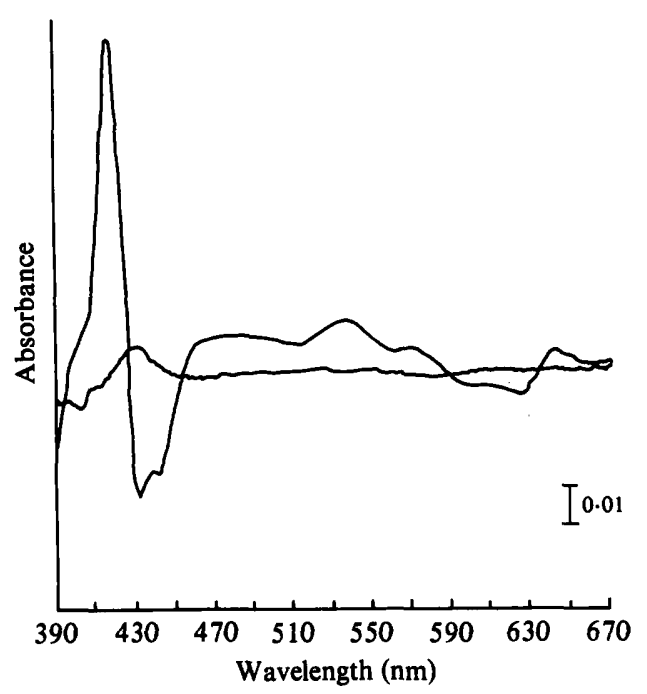

Fig. 3

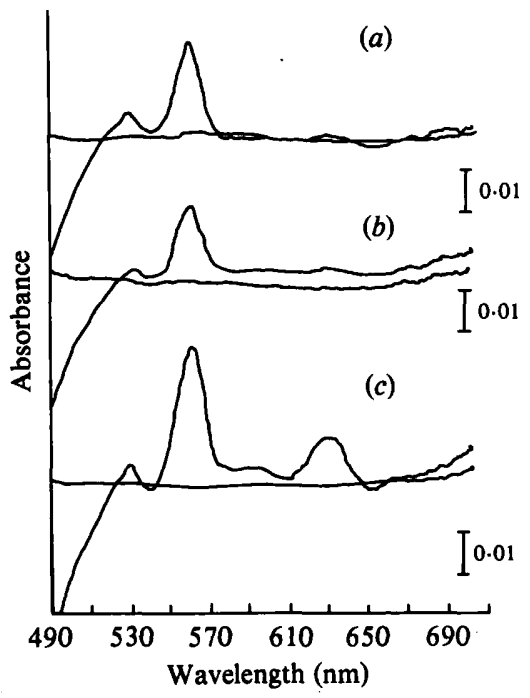

Fig. 4

Fig. 3. Difference spectrum (sodium dithionite-reduced-plus- $\mathrm{CO}$ minus sodium dithionite-reduced) for crude extracts from oxygen-limited (d.o.t. $0 \mathrm{mmHg}$ ) A. calcoaceticus. $D=0 \cdot 1 \mathrm{~h}^{-1}$.

Fig. 4. Sodium dithionite-reduced minus potassium ferricyanide-oxidized difference spectra, prepared from crude extracts of organisms grown at d.o.t. values of $(a) 80 \mathrm{mmHg},(b) 5-10 \mathrm{mmHg}$, and (c) $0 \mathrm{mmHg}$. $D=0.1 \mathrm{~h}^{-1}$. Protein concentrations in the extracts were from 3 to $5 \mathrm{mg} \mathrm{ml}^{-1}$.

Table 3. Measurement of $\rightarrow H^{+} / O$ quotients for $A$. calcoaceticus grown under different nutrient limitations at $D=0.1 h^{-1}$

$\rightarrow \mathrm{H}^{+} / \mathrm{O}$ ratios were measured at the expense of endogenous substrates in all experiments, and are shown as means \pm SD, with the number of replicates per determination in parentheses.

$\begin{array}{ll}\text { Nutrient limitation } & \rightarrow \mathrm{H}^{+} / \mathrm{O} \text { ratio } \\ \text { Succinate } & 4.81 \pm 0.6(16) \\ & 5.09 \pm 0.4(16) \\ & 4.81 \pm 0.2(15) \\ \text { Ammonium } & 4.94 \pm 1.2(22) \\ \text { Oxygen } & 5 \cdot 10 \pm 0.4(17)\end{array}$

\section{$\rightarrow H^{+} / O$ quotients}

Measurements of $\rightarrow \mathrm{H}^{+} / \mathrm{O}$ quotients for organisms grown with succinate-, ammonium- and oxygen-limitation and oxidizing endogenous substrates are recorded in Table 3. Bacteria from all these conditions gave similar quotients with a value of approximately 5 .

\section{Excretion of metabolic products}

During oxygen-limited (but not during succinate-limited) growth there was a discrepancy between succinate utilization and the amounts of $\mathrm{O}_{2}$ consumed and $\mathrm{CO}_{2}$ produced. This indicated incomplete oxidation of the non-assimilated carbon source and led to a search for extracellular carbon intermediates. Supernatants from steady-state cultures $\left(D=0.1 \mathrm{~h}^{-1}\right)$ contained $4.8 \mathrm{mM}$-acetate $\left[q_{\text {acetate }}=0.59 \pm 0.11\right.$ (sD, 9 determinations) $\left.\mathrm{mmol} \mathrm{g}^{-1} \mathrm{~h}^{-1}\right]$. The formation of acetate largely accounted for the discrepancy in the stoichiometry of succinate utilization and explained why the ratio of $m_{\mathrm{O}_{2}}: m_{\text {succinate }}$ for $\mathrm{O}_{2}$-limited cultures was about $1: 1$ whereas it was, as expected for complete oxidation, about 3.5:1 for carbon-limited cultures (Table 1). Acetate was not detected in succinate-limited cultures. 
Table 4. Cytochrome content of bacteria grown at different dissolved oxygen tensions at

$$
D=0.1 h^{-1}
$$

The values were calculated with the absorption coefficients and wavelength pairs used by Asperger $e t$ $a l$. (1978). Analyses were done with crude cell-free extracts. Cytochromes $b$ and $a_{2}(d)$ were estimated from sodium dithionite-reduced minus potassium ferricyanide-oxidized spectra, and cytochrome $o$ was estimated from reduced-plus- $\mathrm{CO}$ minus reduced spectra.

\begin{tabular}{|c|c|c|c|c|}
\hline \multirow{2}{*}{$\begin{array}{l}\text { d.o.t. } \\
\text { (mmHg) }\end{array}$} & \multirow{2}{*}{$\begin{array}{c}\text { Nutrient } \\
\text { limitation }\end{array}$} & \multicolumn{3}{|c|}{$\begin{array}{l}\text { Cytochrome content } \\
\text { [nmol (mg protein) }\end{array}$} \\
\hline & & $a_{2}(d)$ & $b$ & $o$ \\
\hline 80 & carbon & ND & 0.18 & 0.05 \\
\hline 80 & & ND & 0.13 & 0.06 \\
\hline $5-10$ & carbon & ND & 0.13 & 0.06 \\
\hline $5-10$ & & ND & 0.13 & 0.05 \\
\hline 0 & oxygen & 0.14 & 0.26 & 0.07 \\
\hline 0 & & 0.09 & 0.17 & 0.09 \\
\hline
\end{tabular}

ND, Not detected.

\section{DISCUSSION}

The maximum molar growth yields obtained for oxygen and succinate were independent of the aeration conditions studied (Table 2). The $\mathrm{Y}_{\mathrm{O}_{2}}^{\max }$ values give a measure of respiratory efficiency because they are related to the $\mathrm{P} / \mathrm{O}$ ratio by the equation $Y_{\mathrm{O}_{2}}^{\max }=Y_{\mathrm{A}}^{\max }(2 \mathrm{P} / \mathrm{O})$ (Stouthamer, 1979).

Measurements of respiratory efficiency in non-growing cells are provided by the $\rightarrow \mathrm{H}^{+} / \mathrm{O}$ quotients, and the values obtained from cells grown under carbon and ammonium-limited conditions do not vary significantly from those obtained with oxygen-limited cells. It is concluded, therefore, that the respiratory efficiency of $A$. calcoaceticus NCIB 8250 is independent of the aeration conditions under which it is grown. This was also the conclusion of Ensley et al. (1981) with regard to A. calcoaceticus HOl-N. These authors detected the presence of cytochrome $a_{2}(d)$ when their organism was grown in oxygen-limited conditions, and the cytochrome synthesis pattern of NCIB 8250 is consistent with these results (Table 4). Thus, in spite of the synthesis of a redox carrier which has a marked effect on the respiratory efficiency of the nitrogen-fixing Azotobacter spp., A. calcoaceticus consumes energy with the same efficiency with or without detectable levels of cytochrome $a_{2}(d)$. Jones et al. (1977) noted that true molar growth yields of bacteria are not significantly altered by the major cytochrome oxidase moiety but are influenced by the presence or absence of a high-potential, membrane-bound cytochrome $c$; this is a redox carrier which has not been detected in Acinetobacter spp. (this paper; also Whittaker, 1971; Jones \& King, 1972; Asperger et al., 1978; Ensley \& Finnerty, 1980).

If the stoichiometry of proton-driven ADP phosphorylation is 2 then $\rightarrow \mathrm{H}^{+} / \mathrm{O}=2 \mathrm{P} / \mathrm{O}$ ratio. $\mathrm{P} / \mathrm{O}$ ratios, calculated from the $\rightarrow \mathrm{H}^{+} / \mathrm{O}$ quotients given in Table 3 using this equation, are $2 \cdot 41$ to 2.55 for the organism NCIB 8250 . These values are in agreement with those calculated from the data of Jones et al. (1975), who reported a $\rightarrow \mathrm{H}^{+} / \mathrm{O}$ ratio of 5.69 when Acinetobacter lwoffi $4 \mathrm{~B}$ was grown in minimal salts medium with $30 \mathrm{~mm}$-succinate. Later work with lactate-limited cultures produced an average $\rightarrow \mathrm{H}^{+} / \mathrm{O}$ value of 3.7. Meyer \& Jones (1973) and Jones et al. (1975) concluded that proton-translocating loops 0 (transhydrogenase), 1 and 2 are active in $A$. lwoffi 4B, although site 0 is thought to function in the direction of NADPH production in growing cells. Similarly Ensley et al. (1981) suggested that the redox chain of $A$. calcoaceticus HO1-N is divided into two equivalent sites of energy conservation.

Our growth yield data and $\rightarrow \mathrm{H}^{+} / \mathrm{O}$ quotients are in good agreement with similar values reported in the literature, and it is difficult not to arrive at the same conclusions with regard to respiratory efficiency as those already published. However, it is worthwhile to consider that measurements of respiratory efficiency in bacteria using $\rightarrow \mathrm{H}^{+} / \mathrm{O}$ values are predicated on the assumption that two protons are translocated at each site of oxidative phosphorylation. There is evidence to suggest that in mitochondria (Reynfarje \& Lehninger, 1978) and in Paracoccus 
denitrificans (van Verseveld, 1979) the number translocated is 3 to 4 . Ratcliffe et al. (1983) measured $\rightarrow \mathrm{H}^{+} / \mathrm{O}$ ratios of 6 in Rhizobium leguminosarum, which indicated a potential $\mathrm{P} / \mathrm{O}$ ratio of 3 , but low growth yields and rapid proton decay across the membrane led them to suggest that the actual $\mathrm{P} / \mathrm{O}$ ratio was 1.

Determination of respiratory efficiency by measuring growth yields depends upon a knowledge of either $\mathrm{P} / \mathrm{O}$ ratios or $Y_{A}^{\max }$ values, neither of which can be determined directly in aerobes. If the mean $\rightarrow \mathrm{H}^{+} / \mathrm{O}$ quotient of those shown in Table 3, and the mean $Y_{\mathrm{O}_{2}}^{\max }$ value from those shown in Table 1 are inserted into the yield equation $Y_{\mathrm{O}_{2}}^{\max }=Y_{\mathrm{ATP}}^{\max }(2 \mathrm{P} / \mathrm{O})$, then $Y_{\mathrm{ATP}}^{\max }$ becomes: $23.8=Y_{A T P}^{\max }(4.95)$ and $Y_{A T P}^{\max }=4.8 \mathrm{~g} \mathrm{~mol}^{-1}$. This value is very low, particularly when compared with the $10.5 \mathrm{~g} \mathrm{~mol}^{-1}$ originally thought to be a constant for all micro-organisms (Bauchop \& Elsden, 1960), or with the value of $15.4 \mathrm{~g} \mathrm{~mol}^{-1}$ calculated for cells growing on malate in a minimal salts medium (Stouthamer, 1979). Conversely, if either 10.5 or $15.4 \mathrm{~g} \mathrm{~mol}^{-1}$ as the value for $Y_{A T P}^{\max }$ is inserted into the equation then $\mathrm{P} / \mathrm{O}$ ratio values become: $23.8=10.5$ $(2 \mathrm{P} / \mathrm{O})$ and $\mathrm{P} / \mathrm{O}=1 \cdot 1$; and $23 \cdot 8=15.4(2 \mathrm{P} / \mathrm{O})$ and $\mathrm{P} / \mathrm{O}=0.77$.

Thus, either $Y_{\mathrm{ATP}}^{\max }$ or the $\mathrm{P} / \mathrm{O}$ ratio is unusually low. Theoretical values for $Y_{\text {succinate }}^{\max }$ and $Y_{\mathrm{O}_{2}}^{\max }$, calculated for an assumed single site of oxidative phosphorylation (Table 2), are almost identical with the experimentally determined values (Table 1). Similar agreement is achieved between theoretical maximum yield values for growth on lactate (calculations not shown) with an assumed $\mathrm{P} / \mathrm{O}$ ratio of $1\left(Y_{\text {lactate }}^{\max }=38.3 \mathrm{~g} \mathrm{~mol}^{-1}\right.$ and $\left.Y_{\mathrm{O}_{2}}^{\max }=27.8 \mathrm{~g} \mathrm{~mol}^{-1}\right)$, which are close to experimental determinations made by Jones et al. (1977) $\left(Y_{\mathrm{lactate}}^{\max }=35.8 \mathrm{~g} \mathrm{~mol}^{-1}\right.$ and $Y_{\mathrm{O}_{2}}^{\max }=$ $28.7 \mathrm{~g} \mathrm{~mol}^{-1}$ ). Theoretical growth yield values were derived using calculated $Y_{\mathrm{ATP}}^{\max }$ values of 15.4 for succinate and 13.4 for lactate (Stouthamer, 1979). Such theoretical values are often twice those calculated using $\rightarrow \mathrm{H}^{+} / \mathrm{O}$ data and may be an overestimate of the true value. If this is the case then the calculations of theoretical maximum yields on succinate and oxygen could indicate that there are two sites of oxidative phosphorylation rather than one. In considering this alternative the limitations of the proton pulsing method as a measure of respiratory efficiency should be taken into account, and the possibility that the potential $\mathrm{P} / \mathrm{O}$ ratio in $A$. calcoaceticus is 2 , but the actual or effective $\mathrm{P} / \mathrm{O}$ ratio is 1 , be considered as a viable proposition. This may be an explanation for the low growth yields although it would also imply that the $\rightarrow \mathrm{H}^{+} / \mathrm{P}$ ratio is greater than 2 , and there is no evidence presented here to support this suggestion.

Other explanations for the low yields could include excretion of metabolites. In succinatelimited cultures all the carbon was recovered as biomass or carbon dioxide, but in oxygenlimited growth $4.8 \mathrm{mM}$-acetate was detected in steady-state culture supernatants. However, excretion of acetate does not affect the respiratory efficiency since there is no variation in $\rightarrow \mathrm{H}^{+} / \mathrm{O}$ or maximum growth yield when cells are changed from succinate- to oxygen-limited conditions. The metabolic slip reactions suggested by Neijssel \& Tempest (1976) may also be a possible cause of low growth yields, although in energy-limited cultures it might be expected that catabolic and anabolic pathways would be tightly coupled. Acinetobacter spp., although metabolically very versatile, may, as Fewson (1985) suggests on the basis of low yields on a range of growth substrates in batch and continuous culture, be inefficient utilizers of energy. However, differences in yield data for growth on L-mandelate and phenylglyoxalate indicated that two sites of oxidative phosphorylation were present (Fewson, 1985).

Thus there is a growing body of data which suggests that Acinetobacter spp. have two sites of oxidative phosphorylation but for reasons as yet unclear the biomass yield is low. Theoretically calculated yields on succinate and oxygen when compared with experimentally determined values indicate that the effective $\mathrm{P} / \mathrm{O}$ ratio is one.

We are grateful to Professor C. A. Fewson and Dr L. Fixter for discussions and to the Science and Engineering Research Council for the award of a Research Studentship to G. A. Hardy.

\section{REFERENCES}

Ackrell, B. A. C. \& Jones, C. W. $(1971 a)$. The respiratory system of Azotobacter vinelandii. 1. Properties of phosphorylating respiratory membranes. European Journal of Biochemistry 20, 22-28.
Ackrell, B. A. C. \& Jones, C. W. $(1971 b)$. The respiratory system of Azotobacter vinelandii. 2. Oxygen effects. European Journal of Biochemistry 20, 29-35. 
Asperger, O., Kleber, H. P. \& Aurich, H. (1978). Cytochrome composition of Acinetobacter calcoaceticus. Acta biologica et medica germanica 37, 191-198.

BAUChOP, T. \& ELSDEN, S. R. (1960). The growth of microorganisms in relation to their energy supply. Journal of General Microbiology 23, 457-469.

BegGs, J. D. \& Fewson, C. A. (1977). Regulation of synthesis of benzyl alcohol dehydrogenase in Acinetobacter calcoaceticus NCIB 8250. Journal of General Microbiology 103, 127-140.

Carter, I. S. \& Dawes, E. A. (1979). Effect of oxygen concentration and growth rate on glucose metabolism, poly- $\beta$-hydroxybutyrate biosynthesis and respiration of Azotobacter beijerinckii. Journal of General Microbiology 110, 393-400.

Chaney, A. L. \& Marbach, E. P. (1962). Modified reagents for determination of urea and ammonia. Clinical Chemistry 8, 130-132.

Dalton, H. \& Postgate, J. R. (1969). Effect of oxygen on growth of Azotobacter chroococcum in batch and continuous culture. Journal of General Microbiology 54, 463-473.

Drozd, J. \& Postgate, J. R. (1970). Effects of oxygen on acetylene reduction, cytochrome content and respiratory activity of Azotobacter chroococcum. Journal of General Microbiology 63, 63-73.

ENSLEY, B. D. \& FINNERTY, W. R. (1980). Influences of growth substrates and oxygen on the electron transport system in Acinetobacter sp. HOl-N. Journal of Bacteriology 142, 859-868.

Ensley, B. D., Irwin, R. M., Carreira, L. A., Hoffman, P. S., Morgan, T. V. \& Finnerty, W. R. (1981). Effects of growth substrates and respiratory chain composition on bioenergetics in Acinetobacter sp. strain HO1-N. Journal of Bacteriology 148, 508513.

Fewson, C. A. (1985). Growth yields and respiratory efficiency of Acinetobacter calcoaceticus. Journal of General Microbiology 131, 865-872.

HARRISON, D. E. F. (1973). Growth, oxygen, and respiration. CRC Critical Reviews in Microbiology 2, 185-228.

HARRISON, D. E. F. (1976). The regulation of respiration rate in growing bacteria. Advances in Microbial Physiology 14, 243-313.

Harrison, D. E. F. \& Loveless, J. E. (1971). The effect of growth conditions on respiratory activity and growth efficiency in facultative anaerobes grown in chemostat culture. Journal of General Microbiology 68, 35-43.

Herbert, D., Phipps, P. J. \& Tempest, D. W. (1965). The chemostat: design and instrumentation. Laboratory Practice 14, 1150-1161.

Holdeman, L. V., Cato, E. P. \& Moore, W. E. C. (1977). Anaerobe Laboratory Manual, 4th edn, pp. 134-135. Blacksburg: Virginia Polytechnic Institute and State University.

Holz, G. \& Bergmeyer, H. U. (1978). In Principles of Enzymatic Analysis, vol. 3, Section D, Methods for Determination of Metabolites, pp. 1528-1532. Edited by H. U. Bergmeyer. London: Academic Press.

JACKSON, F. A. \& DAWES, E. A. (1976). Regulation of the tricarboxylic acid cycle and poly- $\beta$-hydroxybutyrate metabolism in Azotobacter beijerinckii grown under nitrogen or oxygen limitation. Journal of General Microbiology 97, 303-312.
Jones, C. W., Brice, J. M., Downs, A. J. \& Drozd, J. W. (1975). Bacterial respiration-linked proton translocation and its relationship to respiratorychain composition. European Journal of Biochemistry 52, 265-271.

Jones, C. W., Brice, J. M. \& EdWards, C. (1977). The effect of respiratory chain composition on the growth efficiencies of aerobic bacteria. Archives of Microbiology 115, 85-93.

Jones, M. \& King, H. K. (1972). Particulate malate oxidation in strictly aerobic bacteria: the respiratory chain of Moraxella lwoffi. FEBS Letters 22, 27.7-279.

Keevil, C. W., Hough, J. S. \& Cole, J. A. (1977). The effects of glucose, succinate and $3^{\prime}, 5^{\prime}$-cyclic adenosine monophosphate on the synthesis of the tricarboxylic acid cycle enzymes and respiratory components in Citrobacter freundii. FEMS Microbiology Letters 1, 329-331.

Keevil, C. W., Hough, J. S. \& Cole, J. A. (1979). Regulation of respiratory and fermentative modes of growth of Citrobacter freundii by oxygen, nitrate and glucose. Journal of General Microbiology 113, 83-95.

Meyer, D. J. \& Jones, C. W. (1973). Oxidative phosphorylation in bacteria which contain different cytochrome oxidases. European Journal of Biochemistry 36, 144-151.

Midgley, M. \& DAWES, E. A. (1973). The regulation of transport of glucose and methyl $\alpha$-glucoside in Pseudomonas aeruginosa. Biochemical Journal 132, 141-154.

Milner, H. W., Lawrence, N. S. \& French, C. S. (1950). Colloidal dispersion of chloroplast material. Science 111, 633-634.

Mitchell, C. G. \& DAWES, E. A. (1982). The role of oxygen in the regulation of glucose metabolism, transport and the tricarboxylic acid cycle in Pseudomanas aeruginosa. Journal of General Microbiology 128, 49-59.

MitChell, P. \& MoYLe, J. (1967). Respiration-driven proton translocation in rat liver mitochondria. Biochemical Journal 105, 1147-1162.

Nagai, S., Nishizawa, Y. \& Aiba, S. (1969). Energetics of growth of Azotobacter vinelandii in a glucoselimited chemostat culture. Journal of General Microbiology 59, 163-169.

NeIJSSEL, O. M. \& TEMPEST, D. W. (1976). The role of energy-spilling reactions in the growth of Klebsiella aerogenes NCTC 418 in aerobic chemostat culture. Archives of Microbiology 110, 305-311.

Nishizawa, Y., Nagai, S. \& Aiba, S. (1971). Effect of dissolved oxygen on electron transport system of Azotobacter vinelandii in glucose-limited and oxygenlimited chemostat cultures. Journal of General and Applied Microbiology 17, 131-140.

PIRT, S. J. (1975). Principles of Microbe and Cell Cultivation. Oxford: Blackwell Scientific Publications.

Ratcliffe, H. D., Drozd, J. W. \& Bull, A. T. (1983). The utilization of 5-oxoproline, ammonia and glutamine by Rhizobium leguminosarum in chemostat culture. Journal of General Microbiology 129, 17071712.

Reynafarje, B. \& Lehninger, A. L. (1978). The $\mathrm{K}^{+} /$site and $\mathrm{H}^{+} /$site stoichiometry of mitochondrial electron transport. Journal of Biological Chemistry 253, 6331-6334. 
Robinson, J. \& COOPER, J. M. (1970). Method of determining oxygen concentrations in biological media, suitable for calibration of the oxygen electrode. Analytical Biochemistry 33, 390-399.

SENIOR, P. J., BeECH, G. A., Ritchie, G. A. F. \& DAWES, E. A. (1972). The role of oxygen limitation in the formation of poly- $\beta$-hydroxybutyrate during batch and continuous culture of Azotobacter beijerinckii. Biochemical Journal 128, 1193-1201.

STOUTHAMER, A. H. (1979). The search for correlation between theoretical and experimental growth yields. In International Reviews of Biochemistry. Microbial Biochemistry, vol. 21, pp. 1-47. Edited by J. R. Quayle. Baltimore: University Park Press.

VAN VERSEVELD, H. W. (1979). Influence of environmental factors on the efficiency of energy conservation in Paracoccus denitrificans. PhD thesis, Vrije Universiteit te Amsterdam.

Wales, D. S. \& CARTLedge, T. G. (1980). Effects of glucose repression and anaerobiosis on the activities and subcellular distribution of tricarboxylic acid cycle and associated enzymes in Saccharomyces carlsbergensis. Journal of General Microbiology 116, 93-98.
Ward, A. C., Rowley, B. I. \& Dawes, E. A. (1977). Effect of oxygen and nitrogen limitation on poly- $\beta$ hydroxybutyrate biosynthesis in ammonium grown Azotobacter beijerinckii. Journal of General' Microbiology 102, 61-68.

Whiting, P. H., Midgley, M. \& Dawes, E. A. $(1976 a)$. The regulation of transport of glucose, gluconate and 2-oxogluconate and of glucose catabolism in Pseudomonas aeruginosa. Biochemical Journal 154, 659-668.

Whiting, P. H., Midgley, M. \& Dawes, E. A. $(1976 b)$. The role of glucose limitation in the regulation of the transport of glucose, gluconate and 2-oxogluconate, and of glucose metabolism in Pseudomonas aeruginosa. Journal of General Microbiology 92, 304-310.

Whittaker, P. A. (1971). Terminal respiration in Moraxella lwoffi. Microbios 4, 65-70.

WIMPENNY, J. W. T. (1969). The effect of $E_{\mathrm{h}}$ on regulatory processes in facultative anaerobes. Biotechnology and Bioengineering 11, 623-629. 